\title{
Effects of Low Temperature Storage on the Quality of Different Processing Cultivars of Potato Tubers
}

\author{
Doris Sasaki Tamaki ${ }^{* 1}$, Himoto Jun-Ichi*1 and IтoH Kazuhiko*1 \\ * 1 Graduate School of Agriculture, Hokkaido University \\ Kita 9, Nishi 9, Kita-ku, Sapporo, Hokkaido 060-8589
}

\begin{abstract}
The quality characteristics of four potato cultivars for chips (Toyoshiro, Hokkaikogane, North Chip and Line P982) during storage at $2{ }^{\circ} \mathrm{C}$ and $6{ }^{\circ} \mathrm{C}$ were examined. Chemical composition and physical properties of potato tubers and the appearance of the chips obtained from the potato tubers were evaluated every 30 days for 180 days. Reducing sugar content and chips appearance as well as sprout growth differed depending on the cultivar and storage temperature. The reducing sugar content increased after the first month of storage in all treatments. Sprout growth was completely inhibited in all of the tubers stored at $2{ }^{\circ} \mathrm{C}$, while it was delayed in the tubers stored at $6{ }^{\circ} \mathrm{C}$. Chips obtained from the low temperature resistant cultivars of potato tubers (North Chip and Line P982) stored at $6{ }^{\circ} \mathrm{C}$ for 6 months showed an acceptable color for commercial purposes.
\end{abstract}

(Received Mar. 31, 2003 ; Accepted Aug. 28, 2003)

Due to the seasonal nature of potato production, storage of high quality processing potato tubers is needed to meet the demand for year round processing products. Maintenance of high quality processing potatoes over a long period is an important issue for both growers and processors ${ }^{11}$. Potato tubers for production of chips are stored at temperature above $10^{\circ} \mathrm{C}$, and chemical inhibitors such as iso-propyl-N-(3-chlorphenyl)-carbamate (CIPC) are sprayed on the tubers to prevent sprouting, dehydration and disease. However, due to the increasing health consciousness among consumers, the application of chemical to food products is becoming unpopular ${ }^{2}$. Low temperature storage of potato tubers delays senescent sweetening by slowing physiological aging, sprouting and glycolitic respiration ${ }^{3)}$.

Low temperature storage helps to reduce problems of sprout growth and losses due to disease and rotting without the use of chemicals inhibitors ${ }^{11}$. Also when combined with a high relative humidity environment and low temperature it significantly reduces shrinkage and weight loss during storage. However, potato tubers like many other plant tissues, often undergo a phenomenon known as low temperature sweetening (LTS) when exposed to a low temperature ${ }^{4)}$. This process is a result of increased membrane permeability and starch breakdown. LTS involves the accumulation of reducing sugars (fructose and glucose) and sucrose. Sucrose accumulates in the tuber due to inactivation of the cold labile glycolitic enzymes phosphofructokinase and fructose-6-phosphate phosphotransferase. Conversion of sucrose to glucose and fructose via invertase in cold storage conditions results from the inactivation of an invertase inhibitor ${ }^{3}$.

The color of chips mainly depends on the concentration of reducing sugars. For this reason, high reducing sugar levels are not acceptable for processing potato tubers. The color of fried products is a major factor determining their acceptability by the consumer. The flavor and color of chips are determined by products of the maillard reaction. The reaction results in the formation of brown melanoidin pigments from reactions involving compounds with amino and carbonyl groups ${ }^{2,5} \sim \sim^{\prime}$. The carbonyl component of the browning reaction has been reported to be rate limiting ${ }^{3)}$. As a consequence of this reaction, dark chips with a bitter flavor are obtained. These chips are not acceptable for commercial purposes. To obtain chips of an acceptable color, tubers stored at low temperatures must be reconditioned before they can

* 1 E-mail : Doris SASAKI TAMAKI ; doris@bpe.agr.hokudai.ac.jp, HimoTo Jun-Ichi ; himo@bpe.agr.hokudai.ac.jp, ITOH Kazuhiko;kazu@bpe.agr.hokudai.ac.jp 
be used for frying. This reconditioning process consists of storing the tubers at temperatures between $10 \sim 20^{\circ} \mathrm{C}$ for $2 \sim 4$ weeks ${ }^{8}$.

Development of cultivars for chips has became an important goal of breeding programs and many efforts have been made to produce cultivars that are resistant to LTS and that will produce light colored chips directly from cold $\left(4 \sim 6{ }^{\circ} \mathrm{C}\right)$ storage $^{9)}$ without the need for reconditioning.

The purpose of this study was to evaluate the changes in chemical composition and physical properties of four processing cultivars (low temperature resistant and low temperature susceptible) of potato tubers during storage for 6 months at two temperature regimes.

\section{Materials and Methods}

\section{Materials}

Four different cultivars of potato tubers were used in this experiment. Low temperature susceptible potato tubers ( Toyoshiro and Hokkaikogane cultivars) were harvested at Memuro, Hokkaido, and low temperature resistant potato tubers (North Chip and Line P982) were harvested in Eniwa, Hokkaido in the fall of 2001.

\section{Storage Method}

Tubers of each cultivar were randomized into two lots. The tubers were stored in corrugated cartons at $2{ }^{\circ} \mathrm{C}$ and $6{ }^{\circ} \mathrm{C}$ for 6 months and sampled after $30,60,90,120,150$ and 180 days. The relative humidity in both chambers was above $90 \%$ during the entire period of storage.

\section{Experimental Methods}

(1) Chips Color Chips were obtained by slicing tubers into $2 \mathrm{~mm}$ thick slices and then frying in vegetable oil at $180^{\circ} \mathrm{C}$. An oil bath (Yamato Chemical Co.) was used to fry the chips. Doneness was determined by the absence of bubbles in the frying oil. Chips were drained and crushed into fine pieces, and then the chip color was evaluated using a colorimeter (Minolta CR-200 b). L*, a* and $b^{*}$ values were measured at 5 different points. The color attributes of the chips are expressed in terms of lightness $\left(\mathrm{L}^{*}\right)$ and chroma or saturation $\left(\sqrt{a^{2}+b^{2}}\right)$.

(2) Reducing Sugar Content Fifty grams of potato tissue $(\mathrm{n}=3)$ was blended with $50 \mathrm{~m} \ell$ distilled water, and the homogenate was filtered through 150 $\mathrm{mm}$ filter paper. One $\mathrm{m} \boldsymbol{l}$ of the filtrate obtained was collected and diluted with $4 \mathrm{~m} \ell$ acetonitrile (Kanto
Chem. Co.). The resulting liquid was microfiltrated through a $0.45 \mu \mathrm{m}$ Whatman filter and injected into an HPLC system.

HPLC system (Shimadzu LC-10 $\mathrm{AD}_{\mathrm{VP}}$ ) equipped with a refractive index detector (model RID-10 A) was used to separate and quantify the contents of reducing sugars (fructose and glucose) in the samples. An amino column (NH $2 \mathrm{P}-50$, Shodex Asahipack) and a guard column of the same packing were used. The mobile phase was $75: 25(\mathrm{v} / \mathrm{v})$ acetonitrile: distilled water, run at $40^{\circ} \mathrm{C}$ and $1.0 \mathrm{~m} \ell /$ min. Measurements were carried out in triplicate.

(3) Firmness Firmness of the potato tuber was measured using a rheometer (model NRM-2002 J, Fudoh Co.).

Measurements were made 4 times at different locations on each of 5 tubers.

Acylindrical adaptor with a diameter of $2 \mathrm{~mm}$ was used to measure tuber firmness, and the table speed was set at $30 \mathrm{~cm} / \mathrm{min}$.

(4) Sprout Development The potato tubers were observed daily to determine the day of their breaking of dormancy.

( 5 ) Moisture Content Three potato tubers were each cut into six equally sized portions, and two opposite portions were used to determine the moisture content in the sample. Thirty grams samples were used for measurement, and the samples were dried for 24 hours at $70^{\circ} \mathrm{C}$ in an oven (PV-211 ESPEC Co.).

(6) Specific Gravity Intact potatoes were weighed in air and in water. The potatoes and water were allowed to reach the ambient temperature before the weights were measured. The ratio of the weights in air and in water was calculated to obtain the specific gravity value.

( 7 ) Ascorbic Acid Content Ten grams of potato tissue $(\mathrm{n}=3)$ was blended with $10 \mathrm{~m} \ell$ of $5 \%$ metaphosphoric acid solution, and then the homogenate was centrifuged at $1,000 \mathrm{~g}$ for $5 \mathrm{~min}$ and the supernatant was filtered through $150 \mathrm{~mm}$ filter paper. One $\mathrm{m} \boldsymbol{\ell}$ of the supernatant obtained was collected and microfiltrated through a $0.45 \mu \mathrm{m}$ Whatman filter and injected into the HPLC system.

A Shimadzu LC-10 AD $\mathrm{AP}_{\mathrm{VP}}$ HPLC system equipped with an ultraviolet detector (model SPD-10 A operated at $254 \mathrm{~nm}$ was used to quantify the ascorbic acid contents in the potato samples. An amino column (NH 2 P-50, Shodex Asahipack) and a guard column of the same packing were used. The 
mobile phase was $20 \mathrm{mM} \mathrm{NaH} \mathrm{PO}_{4}+30 \mathrm{mM} \mathrm{H}_{3} \mathrm{PO}_{4}$ $(\mathrm{pH} 2.2) / \mathrm{CH}_{3} \mathrm{CN}(20 / 80)$, run at $30^{\circ} \mathrm{C}$ and $1.0 \mathrm{~m} \ell /$ min. The measurements were carried out in triplicate.

( 8 ) Statistical Analysis Data were subjected to analysis of variance and a least difference test to determine significant differences $(P \leq 0.05)$ among treatments.

\section{Results and Discussion}

\section{Changes in Chips Color}

Fig. 1 Fig. 3 show changes in chips overall appearance as a function of storage time for all of the cultivars studied. In the present study, $\mathrm{L}^{*}$ values below 50 were considered commercially undesirable. Considerable changes in potato chip lightness (Fig. 1) were observed in all samples stored at $2{ }^{\circ} \mathrm{C}$. Storage of tubers at $2{ }^{\circ} \mathrm{C}$ resulted in a rapid decrease in lightness (dark chips) that started in the first month of storage when decreases of more than $20 \mathrm{~L}^{*}$ units were observed. Potato chips obtained from the Toyoshiro and Hokkaikogane cultivars lowered their $\mathrm{L}^{*}$ values to 42 and 48 respectively and were considered unacceptable for commercial purposes. This tendency continued until the end of the storage period. The potato samples developed an undesirable dark color due to the LTS phenomenon and the maillard reaction ${ }^{10), 11}$. No significant difference $(P>0.05)$ was found among the samples stored at $2{ }^{\circ} \mathrm{C}$ after 6 months of storage. These low $\mathrm{L}^{*}$ values made the chips obtained from potatoes that had been stored at this temperature unacceptable for commercial purposes, and reconditioning was required to obtain chips of an acceptable appearance.

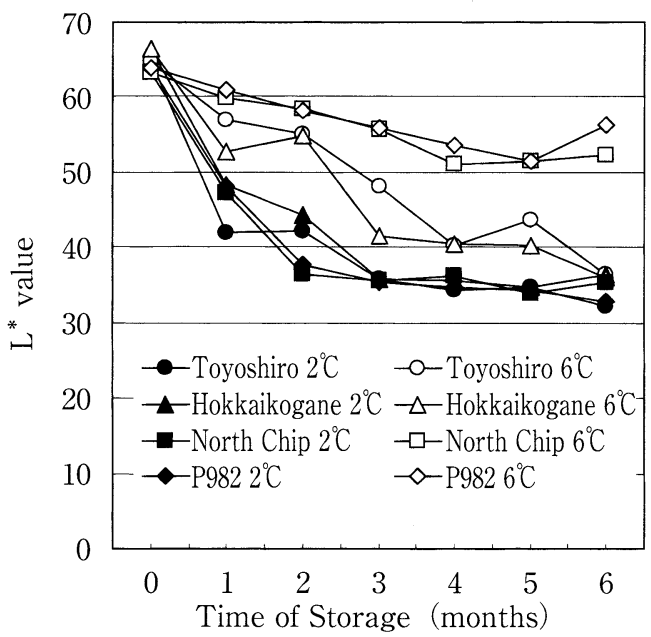

Fig. 1 Changes in $L^{*}$ value during Storage
Two different tendencies were observed in the potato tubers stored at $6{ }^{\circ} \mathrm{C}$. The lightness of chips obtained from the Toyoshiro and Hokkaikogane cultivars, low temperature susceptible cultivars, decreased considerably. The chips produced from these two cultivars were unacceptable for frying without reconditioning treatment of the potatoes. On the other hand, the lightness of chips obtained from the North Chip and Line P982 cultivars, low temperature resistant cultivars, only decreased slightly after 6 months of storage, the chips obtained from Northchip and P982 cultivars presented $\mathrm{L}^{*}$ values of 52 and 56 respectively. The chips obtained from these two cultivars were considered to be acceptable for commercial purposes. A significant difference $(\mathrm{P}<0.05)$ was found between tubers of resistant and susceptible varieties after 6 months of storage.

Color 1 shows the changes in the overall appearance of different cultivars of tubers after 6 months of storage. As was found in cultivars stored at $6{ }^{\circ} \mathrm{C}$, a clear difference was found between the appearance of low temperature susceptible tubers and that of resistant tubers. While the chips obtained from temperature susceptible tubers (Toyoshiro and Hokkaikogane) after 6 months of storage were dark colored, those obtained from the low temperature resistant cultivars (North Chip and Line P982) were an acceptable yellow color, similar to the chips obtained from the tubers of the same cultivars stored at $10^{\circ} \mathrm{C}$.

Fig. 2 shows the changes in the chroma of chips obtained from the potato tubers. In the present study, chroma values below 20 were considered commercially undesirable. After 6 months of storage, chips obtained from North Chip and Line $\mathrm{P}$ 982 cultivars stored at $6{ }^{\circ} \mathrm{C}$ showed an intense color (high chroma), and their chroma values were of 30 and 29 respectively, while those obtained from the Toyoshiro cultivar stored at $2{ }^{\circ} \mathrm{C}$ showed less color intensity, with a decrease in more than 20 chroma units, by the end of the storage period. No significant $(P>0.05)$ difference was found among the samples stored at $2{ }^{\circ} \mathrm{C}$ after 6 months of storage. A significant $(\mathrm{P}<0.05)$ decline in chroma over the period of storage was observed in the chips obtained from Line P982 and North Chip cultivars stored at $6{ }^{\circ} \mathrm{C}$.

\section{Changes in Contents of Reducing Sugars}

Fig. 3 shows the changes in reducing sugar 


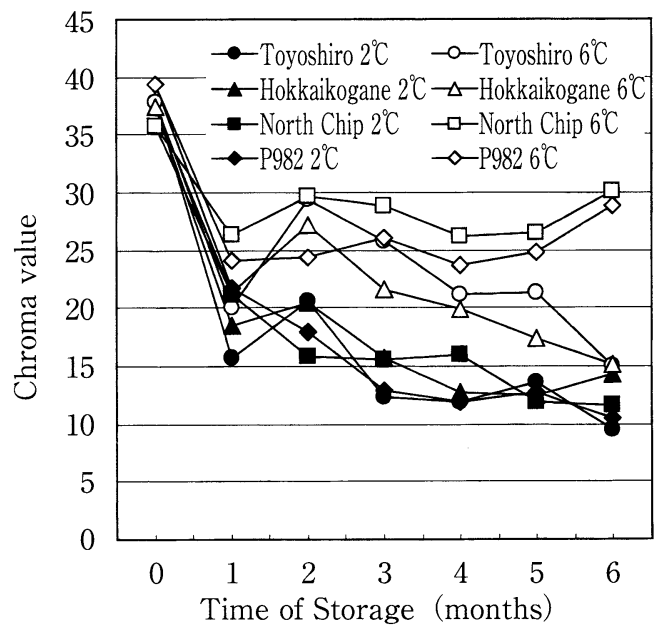

Fig. 2 Changes in Chroma during Storage

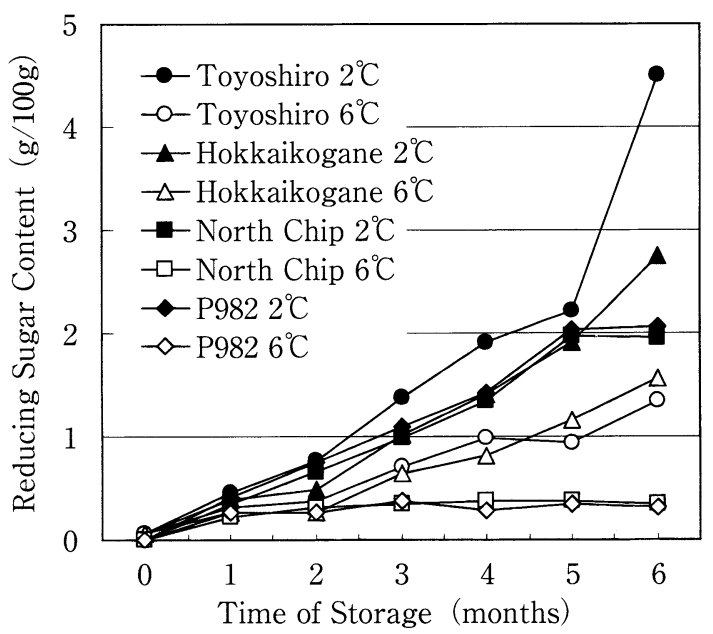

Fig. 3 Changes in Reducing Sugars during Storage

contents as a function of storage time for the cultivars studied. Considerable increases in the reducing sugar content were observed in all samples stored at $2{ }^{\circ} \mathrm{C}$ during the period of storage regardless of the cultivars.

No significant $(p>0.05)$ differences were founded among samples of Hokkaikogane, North Chip and Line P982 stored at $2{ }^{\circ} \mathrm{C}$. After 6 months of storage, a higher reducing sugar content $(4.51 \mathrm{~g} / 100$ g) was found in the Toyoshiro cultivar stored at $2{ }^{\circ} \mathrm{C}$.

North Chip and Line P982 are cultivars resulting from recent efforts to develop potatoes that will provide acceptable chips after being stored at low temperatures (lower reducing sugar content and better chip color). After 6 months of storage at 6 ${ }^{\circ} \mathrm{C}$ these two cultivars showed that a significant ( $\mathrm{P}$ $<0.05)$ difference in the contents of reducing sugar was found from the tubers of Toyoshiro and Hokkaikogane cultivars stored at the same temperature and all the cultivars stored at $2{ }^{\circ} \mathrm{C}$. Their lower reducing sugar contents were reflected in the light yellow color of chips obtained from these two cultivars.

\section{Changes in Firmness}

Fig. 4 shows changes in the potato tuber firmness as a function of storage time for the cultivars studied. After 6 months of storage, a significant ( $p$ $<0.05$ ) difference was found between the firmness of the low temperature susceptible tubers and low temperature resistant tubers.

Low temperature resistant tubers showed less firmness from the beginning of the storage period, a tendency that continued until the end of the storage period.

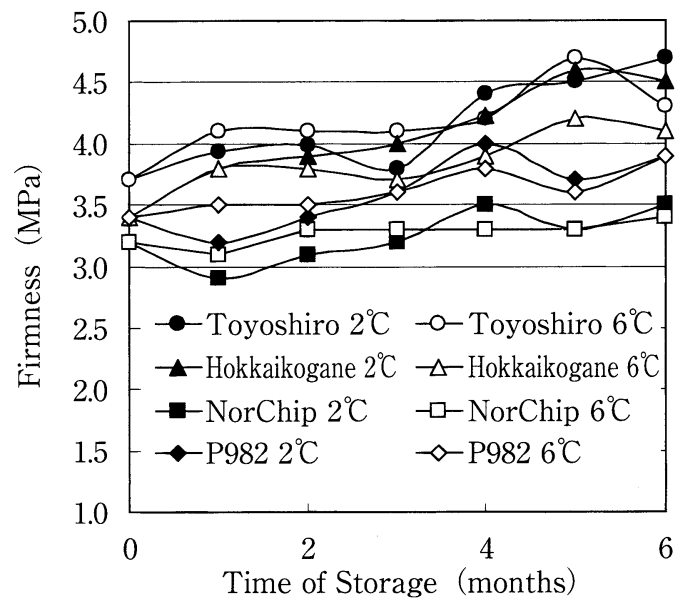

Fig. 4 Changes in Firmness during Storage

\section{Sprout Development}

At temperatures in the range of $4{ }^{\circ} \mathrm{C}$ to $21^{\circ} \mathrm{C}$, the dormant period usually becomes longer with decrease in storage temperature. Sprout growth is slow at temperatures of $5{ }^{\circ} \mathrm{C}$ or less. At temperatures above $5{ }^{\circ} \mathrm{C}$, increasing temperature causes increase in sprout growth until about $20^{\circ} \mathrm{C}^{12}$.

Storage at $2{ }^{\circ} \mathrm{C}$ completely inhibited sprouting in all of the cultivars, while tubers stored at $6{ }^{\circ} \mathrm{C}$ showed different length of time for their breaking of dormancy as shown in Table 1 . Storage at $6{ }^{\circ} \mathrm{C}$ partially delayed the end of the tuber's dormancy period compared with that for tubers stored at $10^{\circ} \mathrm{C}$. The influence of different cultivars can be seen in the length of the dormancy period for tubers stored at $6{ }^{\circ} \mathrm{C}$. Line $\mathrm{P} 982$ showed the shortest period of dormancy, breaking its dormancy after only 70 days from the beginning of storage, and the 
Table 1 Start of Sprout Growth on the different Cutivars

\begin{tabular}{cccc}
\hline & \multicolumn{3}{c}{$\begin{array}{c}\text { Breaking of dormancy } \\
\text { (days) }\end{array}$} \\
\cline { 2 - 4 } Potato Cultivars & \multicolumn{4}{c}{${ }^{\circ} \mathrm{C}$} & $6{ }^{\circ} \mathrm{C}$ & $10^{\circ} \mathrm{C}$ \\
\hline Toyoshiro & - & 80 & 70 \\
Hokkaikogane & - & 115 & 70 \\
North Chip & - & 80 & 40 \\
Line P982 & - & 70 & 30 \\
\hline
\end{tabular}

Hokkaikogane cultivar showed the longest period of dormancy (115 days).

Color 2 shows the sprout development after 3 and 6 months of storage at $6{ }^{\circ} \mathrm{C}$. After 6 months of storage, an advanced stage of sprouting was observed mainly in North Chip and line P982 cultivars.

\section{Changes in Moisture Content}

Fig. 5 shows the changes in the potato moisture content as a function of storage time for the cultivars studied. Decrease in moisture content after 6 months of storage ranged from 3 to $5 \%$. No significant $(\mathrm{P}>0.05)$ differences were found among the cultivars after 6 months of storage.

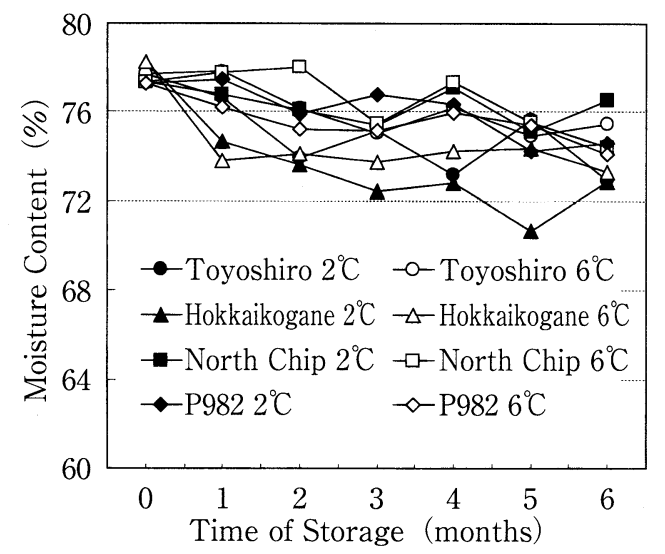

Fig. 5 Changes in Moisture Content during Storage

\section{Changes in Specific Gravity}

The specific gravity of a tuber is an important measure of quality that is used extensively by processors to assess the suitability for the production of french fries and chips since the product yield is greater per unit fresh weight from tubers with a high solid content ${ }^{13)}$.

Changes in specific gravity as a function of storage time for the cultivars studied are shown in Fig. 6. No significant $(P>0.05)$ differences were found among the cultivars after 6 months of storage.

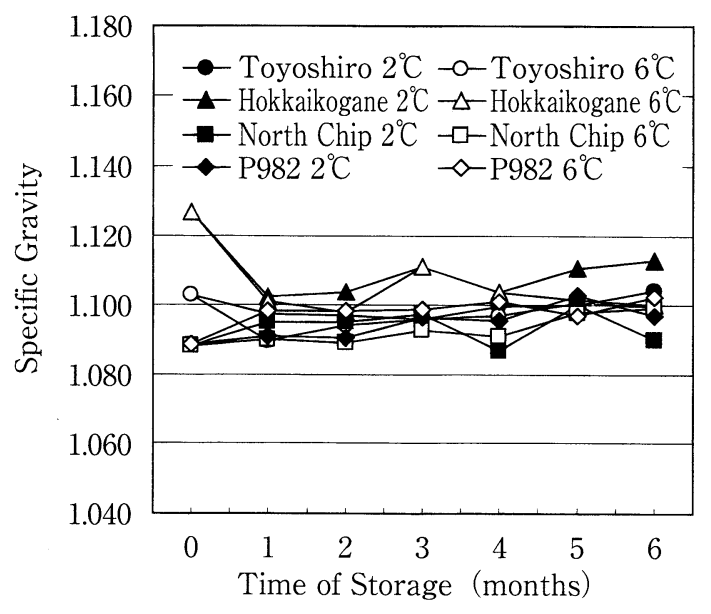

Fig. 6 Changes in Specific Gravity during Storage

\section{Changes in Ascorbic Acid Content}

Fig. 7 shows the changes in ascorbic acid content during storage at $2{ }^{\circ} \mathrm{C}$ and $6{ }^{\circ} \mathrm{C}$.

Ascorbic acid losses during the chipping process, due to the increased surface area exposed to the effects of leaching and heat destruction during processing, have been reported to be $30 \sim 85 \%{ }^{12)}$. Potato tubers with a hgh initial content of ascorbic acid are therefore desirable for nutritional purposes.

The ascorbic acid content of the potato tubers decreased considerably during the first 2 months of storage, regardless of the cultivars or temperature of storage, and remained fairly constant until the end of the storage period.

At the beginning of the storage period, low temperature susceptible cultivars of potato tubers showed higher levels of ascorbic acid but no significant $(\mathrm{P}>0.05)$ differences were found among the cultivars at the end of the storage period.

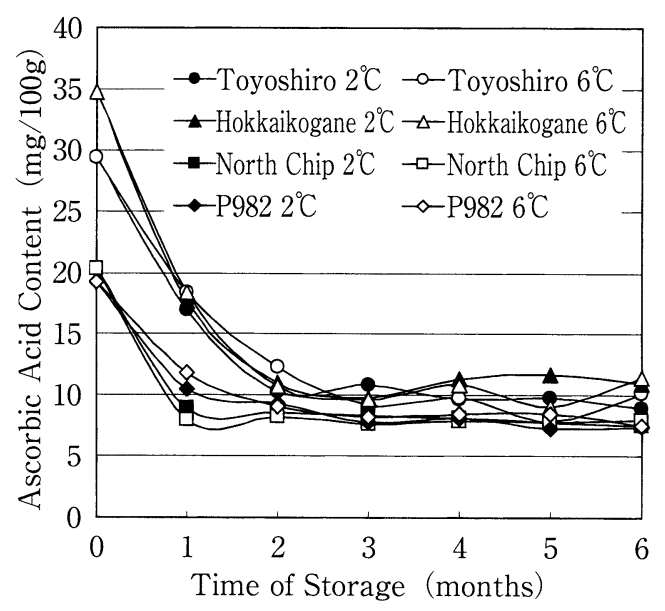

Fig. 7 Changes in Ascorbic Acid content during Storage 
Acknowledgment Our most sincere to Hokuren Agricultural Research Institute in Eniwa, Hokkaido, for supplying the low temperature resistant tubers used in the present study.

\section{Conclusions}

Sprouting was effectively inhibited in all the cultivars stored at $2{ }^{\circ} \mathrm{C}$, but a reconditioning process maybe needed to reduce their high reducing sugar contents before the potato tubers could be used for frying.

Sprouting development was partially delayed in the potato tubers stored at $6{ }^{\circ} \mathrm{C}$. Low temperature resistant tubers (North Chip and Line P982) stored at this temperature maintained a low reducing sugar content, and the color of chips obtained from these tubers was acceptable.

\section{References}

1) Copp, L. P.: The Relationship between Respiration and Chip Color during Long-Term Storage of Potato tubers, American j. Potato Research, 77, 279 287 (2000)

2 ) Murata, Y., Yaptenco, F. F., Noguchi, T., Suzuki, T., Sato, H., Matsumoto, S. and Takano, K.: Property Changes in Potato Tubers (Solanum tuberosum L. ) during Cold Storage at 0 and $10^{\circ} \mathrm{C}$, Food Preservation Science., 26 ( 3 ), 153 160 (2000)

3 ) Herrman, T. J., Love, S. L., Shafi, B. and Dwelle, R. B.: Chipping Performance of Three Processing Potato cultivars during Long-Term storage at two Temperature Regimes, American Potato Journal., 73, 411 425 (1996)

4 ) Coffin, R. H.: Effect of Temperature Storage on Sugar Concentration and Chip Color of Certain Processing Potato Cultivars and Selections, Journal of Food Science., 52 ( 3 ), 639 645 (1987)

5 ) Burton, W. G.: The Potato (Third Edition) (Longman Scientific and Technical, New York), pp. 431 440 (1989)

6 ) Rodriguez-Saona, L. E., Wrolstad, R. E. and PereIRA, C.: Modeling the Contribution of Sugars, Ascorbic acid, Chlorogenic Acid and Amino acids to Non-enzymatic Browning of Potato Chips, Journal of Food Science, 62 ( 5 ), 1001 1005 (1997)

7 ) Rodriguez-Saona, L. E. and Wrolstad, R. E.: Influence of Potato Composition on Chip Color Quality, American Potato Journal, 74 (2), 87〜106 (1997)
8 ) Smith, O.: Potatoes Production Storing and Processing (The AVI Publishing Co., Westport, CN), pp. 458 459 (1977)

9 ) Love, S. L., Pavek, J. J., Thompson-Johns, A. and BoHL, W.: Breeding Progress for Potato Chip Quality in North American cultivars, American $J$. of Potato Res., 75, 27 36 (1998)

10) Parkin, K.: Effects of Low Temperature and Modified Atmosphere on Sugar Accumulation and Chip Color in Potatoes, Journal of Food Science., 55 ( 5 ), 1341 1344 (1990)

11) Illeperuma, C., Schlimme, D. and Solomos, T.: Changes in Sugar and Activities of Sucrose Phosphate Synthase, Sucrose Synthase, and Invertase during Potato Tuber (Ruset Burbank) Reconditioning at $10^{\circ} \mathrm{C}$ in Air and $2.53 \mathrm{kPa}$ Oxygen after Storage for 28 Days at $1{ }^{\circ} \mathrm{C}$, J. Amer. Soc. Hort. Sci., 123 ( 2 ), 311 316 (1998)

12) Woolfe, J.: The Potato in the Human Diet (Cambridge University Press, Cambridge), p. 86 96 (1987)

13) Harris, P. M.: The Potato Crop (Chapman and Hall, London), p. 521 522 (1978)

\section{低温貯蔵した加エ用ジャガイモ の品質変化}

\author{
ササキドリス ${ }^{* 1} \cdot$ 樋元淳一 ${ }^{* 1} \cdot$ 伊藤和彦 ${ }^{* 1}$ \\ * 1 北海道大学大学院農学研究科 \\ （ テ060-8589 北海道札幌市北区北 9 条西 9 丁目）
}

北海道で栽培中および開発中の油加工用ジャガイモの うち, 代表的な 4 品種（トヨシロ, ホッカイコウガネ, ノースチップス, P 982) を用い, $2{ }^{\circ} \mathrm{C}$ おび $6{ }^{\circ} \mathrm{C}$ 条件 で 6 力月貯蔵実験を行った。測定は成分および各種物性 值について行った。その結果, 還元糖含量, ポテトチッ プスの外観および萌芽率は品種と貯蔵温度に影響を受け ることが明らかになり， $2{ }^{\circ} \mathrm{C} て ゙$ 貯蔵した試料の萌芽は 6 カ月間にわたって完全に抑制できたが，還元糖含量は 6 ${ }^{\circ} \mathrm{C}$ で貯蔵した場合に比較してすべての品種とも大きく増 加した。

還元糖，ポテトチップスカラーおよび萌芽率は品種間 および貯蔵温度によって有意な差を認めることができた。

ノースチップスおよびP 982 の両品種は 6 力月間の貯 蔵を行った後でも還元糖含量が他の品種に比較して低い 值を示し, これらを原料に加工したポテトチップスの外 観は $10^{\circ} \mathrm{C}$ で貯蔵した場合とほぼ同程度を示し，消費者を 満足させるのに十分な状態を示した。

(平成 15 年 3 月 31 日受付, 平成 15 年 8 月 27 日受理) 